\title{
PHYSICAL PARAMETERS OF THE CACHIMBAL RIVER SUB-BASIN ASSOCIATED TO LANDSCAPE CHANGE IN PINHEIRAL-RJ, BRAZIL
}

\author{
PARÂMETROS FÍSICOS DA SUB-BACIA DO RIO CACHIMBAL ASSOCIADA À \\ MUDANÇA DE PAISAGEM EM PINHEIRAL-RJ, BRASIL
}

\section{João Henrique GAIA-GOMES ${ }^{1}$; Marcos Gervasio PEREIRA² ${ }^{2}$ Gilsonley Lopes SANTOS ${ }^{3}$; Rafael Coll DELGADO ${ }^{4}$}

1. Doutorando em Agronomia - Ciência do Solo da Universidade Federal Rural do Rio de Janeiro - UFRRJ, Seropédica, RJ, Brasil.; 2. Professor Titular, Doutor, Instituto de Agronomia, Universidade Federal Rural do Rio de Janeiro - UFRRJ, Seropédica, RJ, Brasil, mgervasiopereira01@gmail.com; 3. Pós - Doutorando em Agronomia - Ciência do Solo da Universidade Federal Rural do Rio de Janeiro - UFRRJ, Seropédica, RJ, Brasil.; 4. Professor, Doutor, Instituto de Floresta, Universidade Federal Rural do Rio de Janeiro UFRRJ, Seropédica, RJ, Brasil, rafaelcolldelgado32@gmail.com.

\begin{abstract}
The objective of this study was to characterize the physical parameters of the Cachimbal River Watershed, located in Pinheiral, Rio de Janeiro State, Brazil, and to use the resulting data to identify degradation risks. To achieve this purpose, a Hydrologically Consistent Digital Elevation Model (HCDEM) was generated using contour line, river path, and area boundary data extracted from topographic maps of the cities of Volta Redonda (Page SF-23-ZAV-2) and Piraí (Page SF-23-Z-VI-1). These maps were obtained from the Brazilian Institute of Geography and Statistics, and were rendered at a scale of 1:50,000 ArcGISs version 10.5 software was used to generate the HCDEM, from which the physical parameters were extracted. Results showed that the altitude of the area ranges from $360 \mathrm{~m}$ to $740 \mathrm{~m}$, while the slope varies heterogeneously from $6 \%$ to $28 \%$. The sub-basin has a total area of $104.15 \mathrm{~km}^{2}$, a perimeter of $63.41 \mathrm{~km}$, a main channel length of $21.79 \mathrm{~km}$, and a 5th-order dendritic drainage network. Other parameters include a compactness coefficient of 1.74 , a form factor of 0.34 , and a circularity ratio of 0.33 . These values indicate that the sub-basin is not prone to floods because of its elongated shape. Meanwhile, drainage density was $2.60 \mathrm{~km} \mathrm{~km}^{-2}$, while river density was 5.5 channels $\mathrm{km}^{-2}$; these parameters indicate excellent performance and high potential to generate new channels. Although the roughness coefficient indicates that the area is suitable for agricultural development, the roughness index demonstrates the need to adopt more nuanced agricultural practices that account for the particular features of the area, such as topographic variation and soil characteristics.
\end{abstract}

KEYWORDS: Topographic factors. Morphometric analysis. Erosion. Watershed management.

\section{INTRODUCTION}

A watershed is defined as the area formed by a set of surfaces and a drainage network of watercourses that converge at a single exit point, known as the outlet (VALLE JUNIOR et al., 2012). Watersheds are considered a useful unit of analysis for evaluating man-made environmental effects.

Morphometric characterization is one of the tools used to understand hydrological processes, geomorphological characteristics, and soil use and occupancy form. This makes it particularly useful in discerning the behavior of environmental impacts on river basins. This tool reveals indicators in certain areas that can help to evaluate environmental changes (SIQUEIRA et al., 2012).

This process requires the use of quantitative methodologies based on a number of parameters, specifically the compactness coefficient $(\mathrm{Cc})$, circularity ratio $(\mathrm{Cr})$, form factor $(\mathrm{Ff})$, drainage density (Dd), river density (Rd), roughness coefficient (Rc), and roughness index (Ri) (Christofolletti (1969, 1970, and 1974), Rocha;
Kurts (2001); Cardoso et al. (2006); Villela; Mattos (1975); Machado et al. (2011), Santos et al. (2012); Ferrari et al. (2013), and Silva et al. (2014)). The analysed parameters can be used to determine area size, flooding and erosion susceptibility, landforms, and agricultural aptitude of the area.

Therefore, the objective of this study was to use these physical parameters to characterize the morphometry and in turn identify the degradation risks of the Cachimbal River Sub-Basin (CRSB) in Pinheiral, Rio de Janeiro State (RJ), Brazil.

\section{MATERIAL AND METHODS}

\section{Study area}

The study was conducted in the municipality of Pinheiral, RJ, in the Cachimbal River Sub-Basin (CRSB) (Figure 1). This area is part of the Médio Paraíba Fluminense region and is an element of the Paraíba do Sul River Basin. It is located between latitudes $22^{\circ} 29^{\prime} 03^{\prime} ' S$ and $22^{\circ} 35^{\prime} 27^{\prime \prime} \mathrm{S}$ and between longitudes $43^{\circ} 54^{\prime} 49^{\prime \prime} \mathrm{W}$ and $44^{\circ} 04^{\prime} 05^{\prime \prime} \mathrm{W}$. The study area is structurally 
bounded in the Southeast-Northeast direction (Santos, 2014). AB'Saber (1996 and 1997) showed that this pattern explains the rugged terrain that characterizes the geomorphological features of the region, which is known as the "Mar de Morros" (Figure 1).

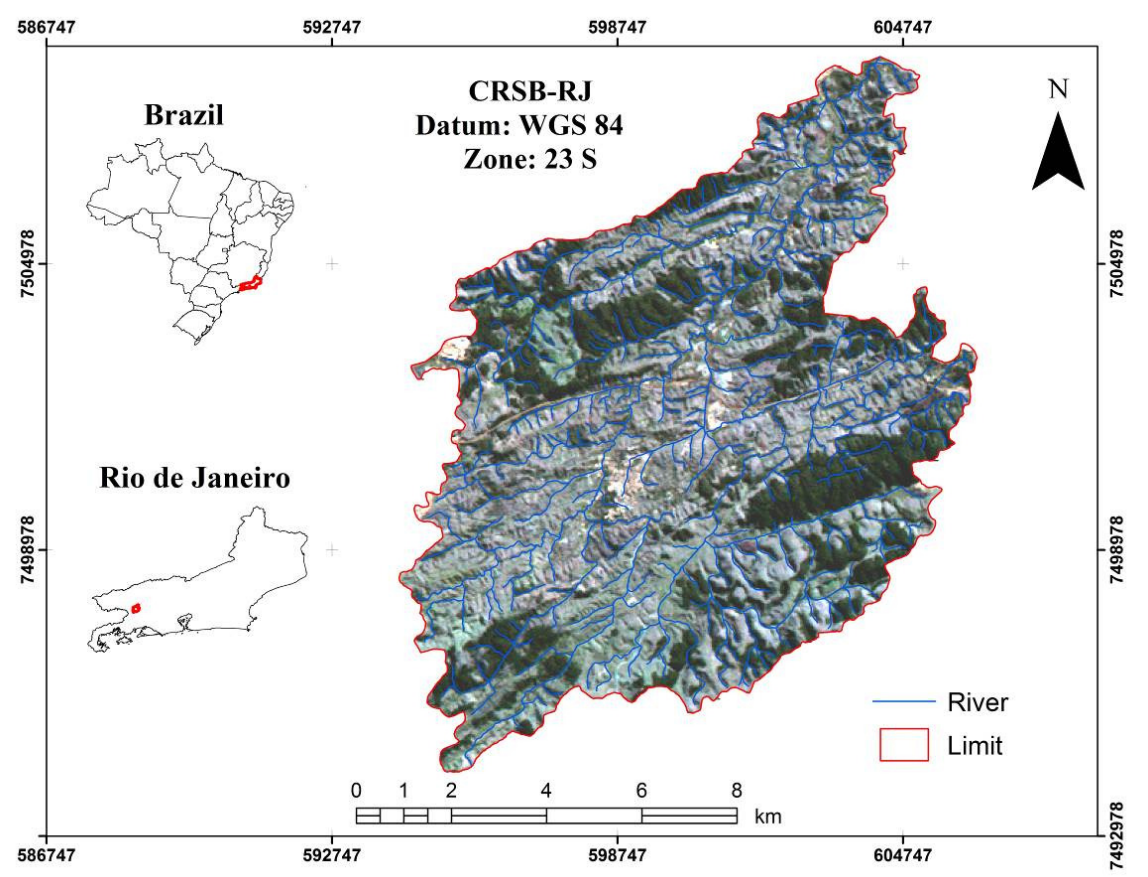

Figure 1. CRSB, Pinheiral, RJ.

The CRSB is contained within the Atlantic Forest, which contains native vegetation typical of a Submontane Semidecidual Seasonal Forest (IBGE, 1992; CONAMA, 1996). The climate, according to the Köppen (1948) classification, is a mix of a temperate dry winter and a rainy summer ( $\mathrm{Cwa}$ ) and of a rainy tropical climate with a dry winter (Aw).

The CRSB has an altitude ranging from 360 $\mathrm{m}$ at the mouth of the Cachimbal River up to $740 \mathrm{~m}$ in the Arrozal mountain range (OLIVEIRA, 1998). The basin's structural valleys and the banks of its main channel are dominated by foothills with varied steepness (72\%), several areas of flattened hilltops (6\%), and narrow floodplains (22\%) (OLIVEIRA, 1998; SANTOS, 2008; SANTOS, 2009; SANTOS, 2014).

The CRSB exhibits several prevalent soil types. The hillsides tend toward Ultisol (Argissolo Vermelho-Amarelo) and Inceptisol (Cambissolo Háplico), while the summit and back slope of the hillsides tend toward Oxisol (Latossolo VermelhoAmarelo) (OLIVEIRA, 1998; MENEZES, 2008).

Topographic maps of the municipalities of Volta Redonda (Page SF-23-Z-A-V-2) and Piraí (Page SF-23-Z-VI-1), obtained from the Brazilian Institute of Geography and Statistics (IBGE) at a scale of 1:50,000, provide contour lines, river paths, and overall boundaries. These data were used to construct the Hydrologically Consistent Digital
Elevation Model (HCDEM). The HCDEM was used to determine the morphometric parameters, according to the division proposed by Tonello (2005), Teodoro et al. (2007), and Souza et al. (2013).

The morphometric parameters were extracted from the HCDEM using ArcGIS version 10.2 software. To obtain Cc, Ff, Cr, Rc, Dd, Rd, Ri, and stream order, it was necessary to use the equations found in Christofolletti (1969, 1970, and 1974), Rocha; Kurts (2001), Cardoso et al. (2006), Villela; Mattos (1975), Machado et al. (2011), Santos et al. (2012), and Ferrari et al. (2013), which are presented below.

$\mathrm{Cc}$ relates the shape of the basin to a circle whose area is equal to that of the basin and establishes a relationship between the perimeter of the basin and the theoretical circumference (Cardoso et al., 2006; Santos et al., 2013). Equation 1 was used to determine $\mathrm{Cc}$ :

$\mathrm{Cc}=0.28 \times \frac{\mathrm{P}}{\sqrt{\mathrm{A}}}$

where:

Cc - compactness coefficient (dimensionless);

$\mathrm{P}$ - perimeter of the basin, $\mathrm{m}$;

A - drainage area, $\mathrm{m}^{2}$. 
According to Tonello et al. (2006) and Teodoro et al. (2007), Ff is expressed as the ratio between the average width and the axial length of the basin (L) (from the estuary to the furthest point in the area), as observed in Equation 2:

$\mathrm{Ff}=\frac{\mathrm{A}}{\mathrm{L}^{2}}$

where:

Ff - form factor, (dimensionless);

A - drainage area of the river basin, $\mathrm{m}^{2}$;

$\mathrm{L}$ - length of the river basin axis, $\mathrm{m}$.

According to Cardoso et al. (2006) and Santos et al. (2013), Cr behaves similarly to Cc, since it tends toward unity as the basin approaches a circular shape and decreases when the shape becomes elongated. The calculation of $\mathrm{Cr}$ was based on Christofoletti (1974), according to Equation 3:

$\mathrm{Cr}=\frac{12,57 * \mathrm{~A}}{\mathrm{P}^{2}}$

where:

$\mathrm{Cr}$ - circularity ratio (dimensionless);

$\mathrm{P}$ - perimeter of the basin, $\mathrm{m}$;

A - drainage area, $\mathrm{m}^{2}$.

$\mathrm{Rc}$ is used to classify land usage in watersheds. It is obtained through the product of Dd and the mean slope gradient of the basin, and was derived based on Rocha \& Kurts (2001), as shown in Equation 4:

$$
\mathrm{Rc}=\mathrm{Hdm} * \mathrm{Dd}
$$

where:

Rc - Roughness coefficient, (dimensionless);

Hdm - mean slope (\%);

Dd - drainage density, $\mathrm{km} \mathrm{km}^{-2}$.

Ri represents the roughness of the soil surface, which is characterized by the spatially distributed set of micro elevations and micro depressions of the terrain (Correa et al., 2012; Ramos et al., 2014). It combines the angle of downward inclination and length of the slope with $\mathrm{Dd}$, which is expressed as a dimensionless number (Rocha et al., 2014). It results from the product of Dd and the altitude range of the basin, and was derived based on Rocha \& Kurts (2001), as shown in Equation 5:

$\mathrm{Ri}=\mathrm{Dd} \times \mathrm{Hm}$

where:

$\mathrm{Ri}$ - roughness index (dimensionless);

Dd - drainage density, $\mathrm{km} \mathrm{km}^{-2}$;

$\mathrm{Hm}$ - altitude range, $\mathrm{m}$.

Dd provides an indication of the drainage efficiency of the basin; it is the total length of the basin watercourses per unit area of the basin. It is a good indication of the degree of development of a drainage system (Cardoso et al., 2006). Dd was derived according to Equation 6 and classified according to Table 1 :

$\operatorname{Dd}=\frac{\sum \mathrm{L}}{\mathrm{A}}$

where:

Dd - drainage density, $\mathrm{km} \mathrm{km}^{-2}$;

$\sum \mathrm{L}$ - total length of watercourses, $\mathrm{km}$;

A - drainage area, $\mathrm{m}^{2}$.

The $\mathrm{Rd}$ is the ratio between the number of watercourses and the area of the river basin. It was derived based on Christofoletti (1970), as shown in Equation 7, and classified according to Lolo (1995) (Table 2).

$\mathrm{Rd}=\frac{\text { number of water courses }}{\mathrm{A}}$

where:

$\mathrm{Rd}$ - river density, channels $\mathrm{km}^{-2}$;

A - drainage area, $\mathrm{m}^{2}$.

Table 1. Dd classification of river basins.

\begin{tabular}{cc}
\hline $\mathrm{Dd}\left(\mathrm{km} \mathrm{km}^{-2}\right)$ & Drainage classification \\
\hline$<0.5$ & Poor \\
$0.5-1.5$ & Regular \\
$1.5-2.5$ & Good \\
$2.5-3.5$ & Very Good \\
$>3.5$ & Exceptionally Well Drained \\
\hline
\end{tabular}

Source: Adapted from Vilella \& Mattos (1975); Beltrame (1994). 
Table 2. Rd classification of river basins.

\begin{tabular}{cc}
\hline $\mathrm{Rd}($ channels km & -2 \\
$<3$ & Classification \\
$3-7$ & Low \\
$7-15$ & Average \\
$>15$ & High \\
\hline
\end{tabular}

Source: Adapted from Lolo (1995).

The stream order was determined by applying the classification established by Strahler (1952) to the drainage network. In this classification, the watercourses originating from springs are considered first order; the channels that arise from the convergence of two channels of equal order have their order calculated by adding the orders of the courses that form it; and the channels that are generated by watercourses of different orders keep the order of greater degree of the source courses.

Elevation and slope were extracted from the HCDEM using ArcGIS version 10.5. The slope is defined as the angle of inclination of the local surface in relation to a horizontal plane. This parameter directly influences pedogenesis, conditioning erosion potential, infiltration, and soil water retention (GALLANT; WILSON, 2000;
SCHIMIDT ET AL., 2003; PINHEIRO, 2012). This was classified according to Santos et al. (2015).

\section{RESULTS AND DISCUSSION}

The CRSB has a total area of $104.15 \mathrm{~km}^{2}$, a perimeter of $63.41 \mathrm{~km}$, and a main course length of $21.79 \mathrm{~km}$ and other parameters obtained are showed in Table 3. Rodrigues et al. (2016) observed a different pattern analyzing the Prata-Pará Igarapé basin, where they obtained values of $115.283 \mathrm{~km}^{2}$ and $70.151 \mathrm{~km}$ for the area and perimeter, respectively. The dimensions of a river basin and its morphometric attributes are responsible for its interior dynamics. Cecílio et al. (2013) state that the larger the area, the greater amount of time available for the hydrographic channels to contribute jointly to the drainage area, thus reducing the potential for flood susceptibility.

Table 3. Physical parameters of the CRSB.

\begin{tabular}{ccc}
\hline Physical parameters & Unit & Values \\
\hline Area & $\mathrm{km}^{2}$ & 104.15 \\
Perimeter & $\mathrm{km}$ & 63.41 \\
Ff & ---- & 0.34 \\
Cc & --- & 1.74 \\
Cr & --- & 0.33 \\
Minimum altitude & $\mathrm{M}$ & 360.00 \\
Average altitude & $\mathrm{M}$ & 550.00 \\
Maximum altitude & $\mathrm{M}$ & 740.00 \\
Altitude range & $\mathrm{M}$ & 380.00 \\
Minimum slope & $\%$ & 0.00 \\
Average slope & $\%$ & 20.87 \\
Maximum slope & $\%$ & 181.35 \\
Rc & --- & 0.54 \\
Length of the main river & $\mathrm{km}^{2}$ & 21.79 \\
Total length of watercourses & $\mathrm{km}^{-}$ & 271.35 \\
Basin order & --- & 5 \\
Dd & $\mathrm{km} \mathrm{km}^{-2}$ & 2.60 \\
Rd & channels km & 5.55 \\
Ri & ---- & 988.00 \\
\hline
\end{tabular}

Ff, $\mathrm{Cc}$, and $\mathrm{Cr}$ were 0.34, 1.74, and 0.33, respectively. These values indicate that the subbasin has an elongated shape. This facilitates water runoff (TORRES et al., 2011), thereby decreasing flooding susceptibility under normal precipitation conditions (CARDOSO et al., 2006). Tonello et al. (2006) and Rocha et al. (2014) also observed an elongated shape when studying the morphometry of the Cachoeira das Pombas basin in Guanhães, Minas 
Gerais state (MG) and the Santana River Sub-basin in Rio Pardo de Minas, MG.

Figure 2 shows the altitude measurements of the study area, which vary from 360 to 744 meters. Again, this wide range is characteristic of the terrain in this "Mar do Morros" region. The terrain can be considered one of the main morphometric conditioning attributes in the dynamics of a watershed, acting along with slope, slope exposure, surface curvature, drainage conditions, distribution of structural attributes, and vegetation (OLIVEIRA et al., 2013).

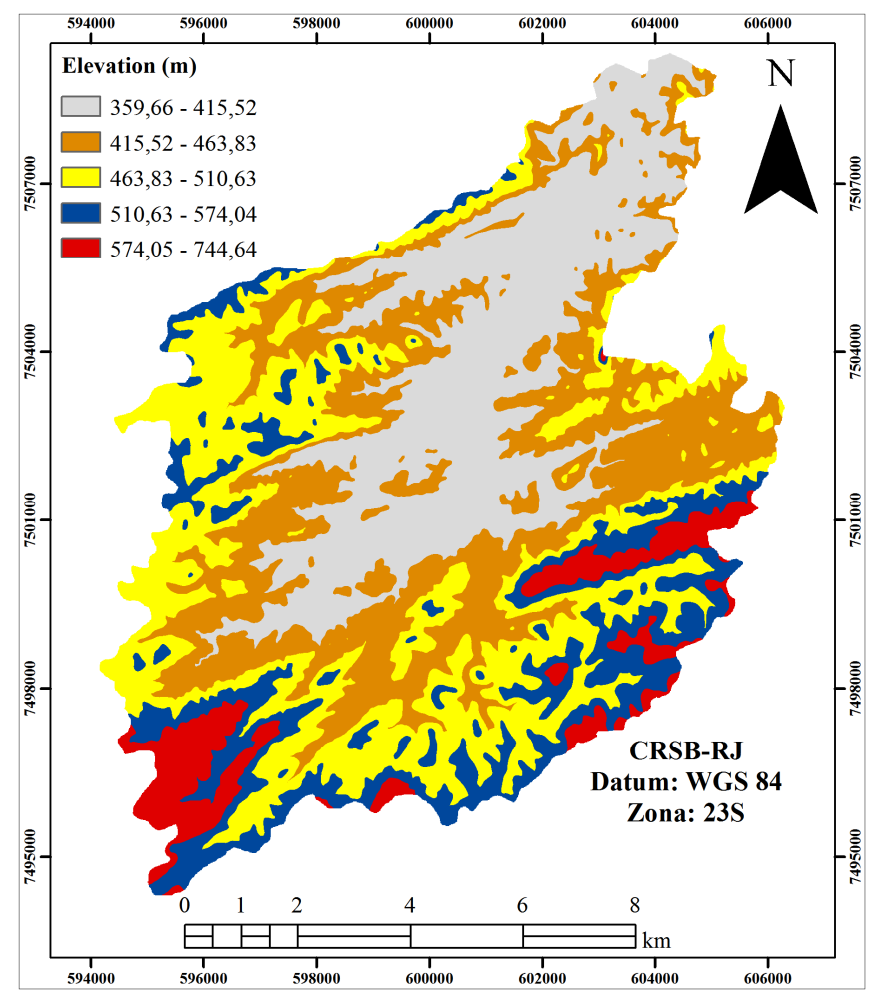

Figure 2. CRSB elevation map.

Table 4 shows that the "415.52 to $463.83 \mathrm{~m}$ " class represents the highest percentage of the subbasin area, totaling $28.0 \%$, while the "574.04 to $744.64 \mathrm{~m}$ " class accounts for the lowest percentage of the area, at $6.0 \%$.

Figure 3 shows the model of the slope and its configuration in the sub-basin. The slope ranged from $0 \%$ to $181.37 \%$ and showed a large number of slightly undular, undular, and strongly undular slope classes, as can be seen in Table 5 .

The slope affects the surface and subsurface water flow velocity, and consequently the soil water level and erosive potential. Slope and vegetation are fundamental in watershed management, since the removal of vegetation can combine with the dynamic effects of slope to elicit erosion and, as a result, environmental degradation (CARDOSO et al., 2006).

Silva et al. (2007) showed that the accumulation of organic matter and the degree of soil humification are strongly correlated with slope. In particular, organic carbon content correlates strongly and negatively with slope.

Table 4. Physical parameters of the CRSB.

\begin{tabular}{cc}
\hline Classes $(\mathrm{m})$ & Area $(\%)$ \\
\hline 359.66 to 415.52 & 26.0 \\
415.52 to 463.83 & 28.0 \\
463.83 to 510.63 & 26.0 \\
510.63 to 574.04 & 14.0 \\
574.04 to 744.64 & 6.0 \\
\hline
\end{tabular}




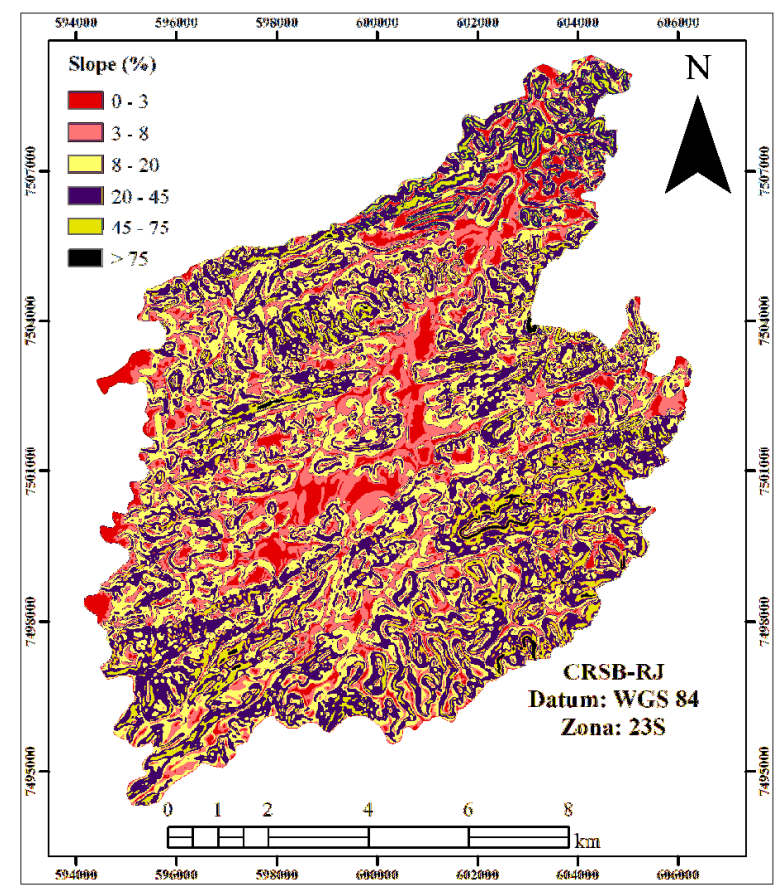

Figure 3. CRSB slope map.

Table 5. Slope distribution in classes.

\begin{tabular}{cc}
\hline Classes & Area (\%) \\
\hline Level (0 to 3) & 10.0 \\
Slightly Undular (3 to 8) & 18.0 \\
Undular (8 to 20) & 29.0 \\
Strongly Undular (20 to 45) & 35.0 \\
Mountainous (45 to 75) & 9.0 \\
Steep (> 75) & 1.0 \\
\hline
\end{tabular}

Source: Adapted from Santos et al. (2013).

The Rc for the CRSB was 0.54, which makes the area suitable for farming. The same pattern was observed by Baracuhy et al. (2003), who found that mini basins, for the most part, are apt for agricultural use. However, field visits are necessary before strongly recommending the region for agricultural development, since the provided value is an average for the entire area and does not reflect local variation.

The measured Ri was 988, which indicates that the sub-basin has steep, extended slopes (POLIZEL; ROSSETTI, 2013). The rougher the surface, the less erosive tendency there is; rough surfaces decrease flow energy, as opposed to smooth surfaces, which have far greater erosive potential. This $\mathrm{Ri}$ value has additional implications when considering overall rainfall and the various kinds of soils in the sub-basin. Ultisol (Argissolos) and Inceptsol (Cambissolos) dominate the summit and back slope of this region, while Fragiudult (Planosols) and Aquent (Gleissolos) occur in the foot slope (COSTA, 2015); this means that the erosive process differs between the two, with erosion being more pronounced at higher altitudes.

Although Rc indicates the suitability of the area for farming, the measured $\mathrm{Ri}$ value demonstrates the need to adopt more nuanced agricultural practices. This value takes into account the particular features of the area, highlighting the variation in terrain and soil characteristics.

The order of the watercourses represents the degree of branching in the river basin. This subbasin was classified as 5th order (Figure 4), which indicates a well-branched drainage system; these results are consistent with the pattern found by Abdala et al. (2009). Cunha et al. (2007) state that the degree of branching is directly proportional to the size of the watercourses. According to Saito (2011) and Soares et al. (2014), the greater the number of branches in the river network, the more efficient its drainage system will be. 


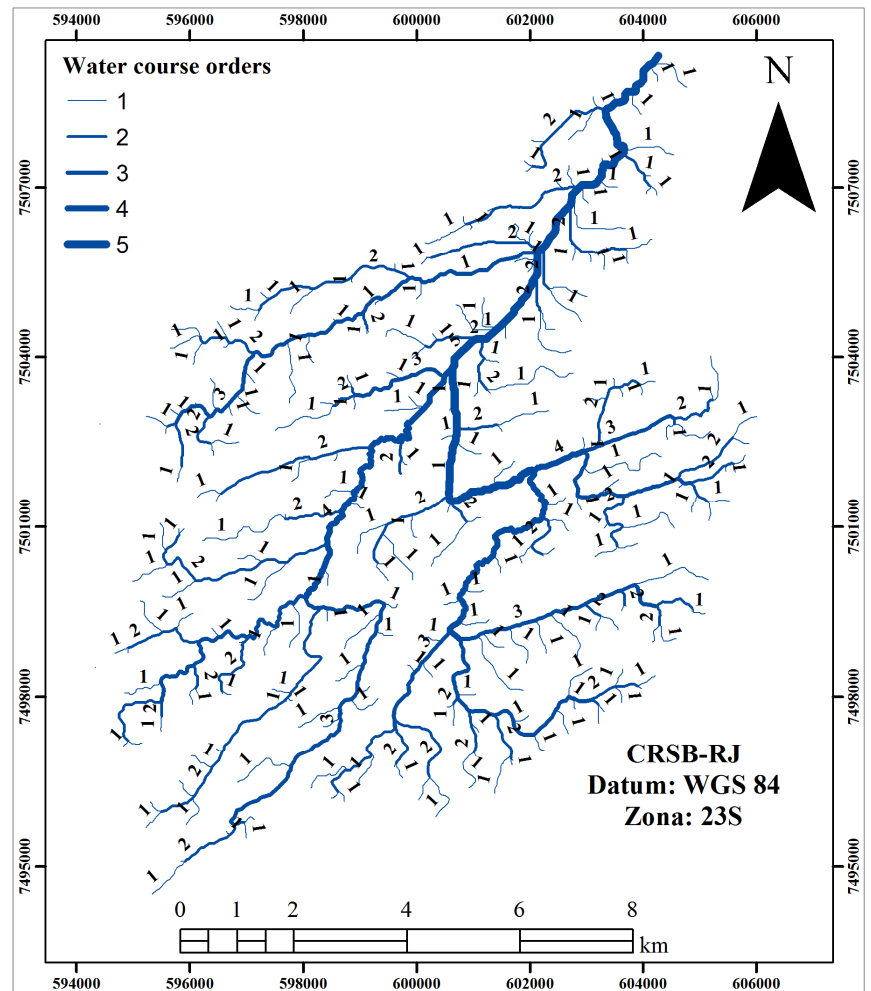

Figure 4. Map of the watercourse orders in the CRSB.

The Dd of the region was $2.60 \mathrm{~km} \mathrm{~km}^{-2}$, indicating that the studied area has very good drainage. Kravchenko (1998), Tonello et al. (2006), and Carvalho et al. (2009) have discussed how low Dd values are found in regions with low intensity, minimally concentrated rainfall, and parent material composed of permeable rocks. These factors may be related to their degree of consolidation.

Vieira et al. (2012) studied the morphometry and water quality of the Sapecado Stream Micro basin which is rooted in the aforementioned tributary in Uberaba, MG. They found a Dd of 1.49 $\mathrm{km} \mathrm{km}$, which is within the range of regular drainage. This classification is consistent with the one performed by Stipp et al. (2010), which gives a value of $1.33 \mathrm{~km} \mathrm{~km}^{-2}$. These measurements differ from those taken by Silva et al. (2014) of the Igarapé Canela Fina and Igarapé Preto River Basins, both of which are located in Cruzeiro do Sul, Acre. Their study gave Dd values of 0.83 and 0.86 , respectively. According to Machado et al. (2011), areas with high Dd values have a greater tendency toward erosion, meaning that they require soil management.

The Rd observed for the CRSB was 5.55 channels $\mathrm{km}^{-2}$. Lana et al. (2001) and Santos et al. (2012) consider Rd as an indicator of whether subbasins will form new channels, asserting that values above 2 channels $\mathrm{km}^{-2}$ indicate high potential.
Therefore, the CRSB, with its average Rd value, is very likely to generate new channels in the future.

Oliveira; Antônio (2015) observed an Rd of 0.38 channel $\mathrm{km}^{-2}$ when they assessed the Maxixe Basin. They characterized this as a low Rd, meaning that the emergence of new channels would be difficult. The relationship between the parameters observed in this study, namely that Dd is greater than $\mathrm{Rd}$, indicates the need for structural control in the analyzed basin (FRANCO; SANTO, 2015).

\section{CONCLUSIONS}

The area is not susceptible to flooding, since the CRSB has an elongated shape.

The sub-basin has a dendritic drainage pattern, 5th degree stream order, and very large Dd. In particular, the average $\mathrm{Rd}$ value is indicative of a high potential to generate new channels.

The area also has a high altitude range and overall steepness. Thus, the surface runoff in the CRSB occurs slowly, and erosive processes develop gradually.

Although Rc indicates agricultural capacity for farming, Ri demonstrates the need to adopt more nuanced agricultural practices that take the particular features of the area into account and that recognize variations in terrain and soil characteristics. 
The morphometric characterization of the CRSB proved successful and highly practical in determining the physical parameters of the area of study. This suggests that this tool can be successfully applied in other locations.

RESUMO: O objetivo deste estudo foi caracterizar os parâmetros físicos da sub-bacia hidrográfica do ribeirão Cachimbal, Pinheiral-RJ, Brasil, a fim de se identificar os riscos à degradação. Para isso foi gerado o Modelo Digital de Elevação Hidrologicamente Consistente (MDEHC) através a partir das cartas topográficas dos municípios de Volta Redonda (Folha SF-23-Z-A-V-2) e Piraí (Folha SF-23-Z-VI-1), obtidas no Instituto Brasileiro de Geografia e Estatística na escala de 1:50.000, onde foram extraídas as curvas de nível, rios e limite. A confecção foi realizada utilizando o software ArcGIS versão 10.5. A obtenção dos parâmetros físicos foi realizada sob o MDEHC. Verificou-se que a altimetria varia de $360 \mathrm{~m}$ a $740 \mathrm{~m}$ e a declividade de $6 \%$ a $28 \%$, estando elas apresentando padrão de distribuição heterogêneo. A sub-bacia possui área total de $104.15 \mathrm{~km}^{2}$, perímetro de $63.41 \mathrm{~km}$, com comprimento do canal principal de $21.79 \mathrm{~km}$ e rede de drenagem de $5^{\mathrm{a}}$ ordem, com padrão dendrítico; coeficiente de compacidade (Kc) de 1.74; coeficiente de forma (Kf) de 0.34, índice de circularidade (IC) de 0.33; que indicam que a sub bacia não apresenta propensão a enchentes, pois possui formato alongado. Os valores encontrados para densidade de drenagem (Dd) foram de $2.60 \mathrm{~km} \mathrm{~km}{ }^{-2}$ e a para densidade hidrográfica (Dh) de 5.5 canais $\mathrm{km}^{-2}$, o que classificou a área com Dd muito boa e Dh com elevado potencial para gerar novos canais. Dessa forma o escoamento superficial ocorre de forma lenta, e a formação de processos erosivos ocorre gradualmente. Apesar do coeficiente de rugosidade $(\mathrm{Cr})$ indicar aptidão agrícola para agricultura, o índice de rugosidade (Ir) verificado, demonstra a necessidade da adoção de um conjunto de práticas agrícolas mais conservacionistas, levando em levando em consideração as particularidades da área, com destaque para as variações do relevo e características do solo associadas à paisagem da bacia hidrográfica.

PALAVRAS-CHAVE: Fatores topográficos. Análise morfométrica. Erosão. Manejo de bacias hidrográficas.

\section{REFERENCES}

AB'SABER, A. N. Domínios morfoclimáticos e solos do Brasil. In: ALVAREZ, V. H.; FONTES, L. E. F.; FONTES, M. P. F. Os solos nos grandes domínios morfoclimáticos do Brasil e o desenvolvimento sustentável. Viçosa: Sociedade Brasileira de Ciência do Solo e UFV, p. 1-18, 1996.

AB'SABER, A. N.; TUNDISI, G. T.; FORNERIS, L.; MARINO, M. C.; ROCHA, O.; TUNDISI,T.; SCHAEFFER-NOVELLI, Y; VUONO, Y. S.; WATANABE, S. Glossário de ecologia. Academia de Ciência do Estado de São Paulo (ACIESP). São Paulo, n. 103, 352 p., 1997.

BARACUHY, J. G. V. et al. Deterioração físico-conservacionista da microbacia hidrográfica do riacho Paus Brancos, Campina Grande, PB. Revista Brasileira de Engenharia Agrícola e Ambiental, v. 7, n. 1, p. 159164, 2003. https://doi.org/10.1590/S1415-43662003000100026

CARDOSO, C. A.; DIAS, H. C. T.; SOARES, C. P. B.; MARTINS, S. V. Caracterização morfométrica da bacia hidrográfica do rio Debossan, Nova Friburgo, RJ. Revista Árvore, v. 30, n. 2, p. 241-248, 2006. https://doi.org/10.1590/S0100-67622006000200011 https://doi.org/10.1590/S0100-67622006000200012

CARVALHO, W. M. DE C.; VIEIRA, E. DE O.; ROCHA, J. M. J.; PEREIRA, A. K. DOS S.; CECÍLIO, R. A. Delimitação de bacia hidrográfica em região montanhosa a partir de diferentes modelos digitais de elevação. Revista Semina: Ciências Agrárias, v. 34, n. 5, p. 2007-2024, 2013. https://doi.org/10.5433/16790359.2013v34n5p2007

CHRISTOFOLETTI, A. Análise morfométrica de bacias hidrográficas no Planalto de Poços de Caldas. Rio Claro: Instituto de Geociências, Universidade Estadual Paulista, 1970. 375f. (Tese de Livre Docência).

CHRISTOFOLETTI, A. Análise morfométrica de bacias hidrográficas. Noticia Geomorfológica, v. 9, n. 18, p. 35-64, 1969. 
CHRISTOFOLETTI, A. Geomorfologia. São Paulo: Edgard Blucher, 1974. 150p.

CONAMA. Resolução 006 de 4 de maio de 1994, Ministério do Meio Ambiente. Disponível em:<http:// www.mma.gov.br/conama/legiano1.cfm>. Acesso em: 05 de junho de 2015.

CORREA, I. M. C.; BERTOL, I.; RAMOS, J. C.; TAKIZAWA, M. M. Rugosidade da Superfície de um Cambissolo Húmico Relacionada com o Preparo e Compactação do Solo sob Chuva Natural. Revista Brasileira de Ciência do Solo, n. 36, p. 567-576, 2012. https://doi.org/10.1590/S0100-06832012000200026

COSTA, E. M. Mapeamento digital de solos por regressão logística múltipla em ambiente de Mar de Morros em Pinheiral, RJ. 2015. 135f. Dissertação (Mestrado em Agronomia, Ciência do Solo). Instituto de Agronomia, Departamento de Solos, Universidade Federal Rural do Rio de Janeiro, Seropédica, RJ, 2015.

FERRARI, J. L.; SILVA, S. F.; SANTOS, A. R.; GARCIA, R. F. Análise morfométrica da sub-bacia hidrográfica do córrego Horizonte Alegre, ES. Revista Brasileira de Ciências Agrárias, v. 8, n. 2, p. 181188, 2013. https://doi.org/10.5039/agraria.v8i2a1575

FRANCO, A. C. V.; SANTO, M. A. D. Contribuição da Morfometria para o Estudo das Inundações na Subbacia do Rio Luís Alves/SC. Revista Mercator, v. 14, n. 3, p. 151-167, 2015. https://doi.org/10.4215/RM2015.1403.0009

GALLANT, J. C.; WILSON, J. P. Primary topographic attributes. In: WILSON, J. P.;GALANT, J. C.(Eds.) Terrain Analysis: Principles and applications. New York: John Wiley \& Sons. p. 51-85. 2000.

INSTITUTO BRASILEIRO DE GEOGRAFIA E ESTATÍSTICA. Manual técnico da vegetação brasileira. IBGE, Rio de Janeiro, 92 p., 1992.

KOPPEN, W. Climatologia: con un estudio de los climas de la tierra. México: Fondo de Cultura Econômica, $1948,488 \mathrm{p}$.

KRAVCHENKO, A. Aerofotointerpretação - Fotografia Aérea à Serviço da Agricultura. Goiânia, GO: Escola de Agronomia - UFG, 1998.

LANA, C. L.; ALVES, J. M. de P.; CASTRO, P de T. A. Análise morfométrica da bacia do rio Tanque, MGBrasil. Revista Escola de Minas, Ouro Preto, v. 54, n. 2, 2001.

LOLLO, J. A. O uso da técnica de avaliação do terreno no processo de elaboração do mapeamento geotécnico: sistematização e aplicação na quadrícula de Campinas. 1995. Tese (Doutorado em Geotecnia) Escola de Engenharia de São Carlos, Universidade de São Paulo, São Carlos, 1995.

MACHADO, R. A. S.; LOBÃO, J. S. B.; VALE, R. M. C.; SOUZA, A. P. M. J. Análise de bacias hidrográficas como suporte a definição e elaboração de indicadores para a gestão ambiental a partir do uso de geotecnologias. In: Simpósio Brasileiro de Sensoriamento Remoto - SBSR, 15, 2011, Curitiba.São José dos Campos: INPE, 2011.

MENEZES, C. E. G. Integridade de paisagem, manejo e atributos do solo no Médio Vale do Paraíba do Sul, Pinheiral-RJ. 2008. 172 f. Tese (Doutorado em Agronomia - Ciência do Solo). Universidade Federal Rural do Rio de Janeiro, 2008.

OLIVEIRA, B. R.; ANTÔNIO, G. B. Caracterização da bacia do Maxixe com auxílio de Sistemas de Informação Geográficas. Revista Eletrônica em Gestão, Educação e Tecnologia Ambiental, v. 19, n. 3. 2015. 
OLIVEIRA, J. A. Caracterização física da Bacia do Ribeirão Cachimbal-Pinheiral (RJ) e de suas principais paisagens degradadas. 1998. 142 f. Dissertação (Mestrado). Universidade Federal Rural do Rio de Janeiro, Pós-Graduação em Agronomia, Ciência do Solo, Seropédica, RJ, 1998.

OLIVEIRA, L. F. C. de; CALIL; P. M.; RODRIGUES, C.; KLIEMANN, H. J.; OLIVEIRA, V. A. de. Potencial do uso dos solos da bacia hidrográfica do alto rio Meia Ponte, Goiás. Revista Ambiente \& Água An Interdisciplinary Journal of Applied Science: v. 8, n. 1, 2013.

OLIVEIRA, L. F. C. de; CALIL; P. M.; RODRIGUES, C.; KLIEMANN, H. J.; OLIVEIRA, V. A. de. Potencial do uso dos solos da bacia hidrográfica do alto rio Meia Ponte, Goiás. Revista Ambiente \& Água An Interdisciplinary Journal of Applied Science: v. 8, n.1, 2013.

PINHEIRO, E. S. Comparação entre dados altimétricos SRTM, cartas topográficas e GPS: numa área com relevo escarpado. Revista Brasileira de Cartografia. Rio de Janeiro: ABC, n. 58, v. 1, 9p, 2006.

POLIZEL, S. P.; ROSSETTI, D. de F. Análise morfométrica da bacia hidrográfica do córrego Tiradentes no município de Rio Bananal-ES. Anais XVI Simpósio Brasileiro de Sensoriamento Remoto - SBSR, Foz do Iguaçu, 2013.

RAMOS, J. C.; BERTOL, I.; BARBOSA, F. T., MARIOTI, J.; WERNER, R. DE S. Influência das Condições de Superfície e do Cultivo do Solo na Erosão Hídrica em um Cambissolo Húmico. Revista Brasileira de Ciência do Solo, 1587-1600, 2014. https://doi.org/10.1590/S0100-06832014000500024

ROCHA, J. S. M.; KURTS, S. M. J. M. Manual de manejo integrado de bacias hidrográficas. 4. ed. Santa Maria: Universidade Federal de Santa Maria, 120p., 2001.

ROCHA, R. M.; LUCAS, A. A. T.; ALMEIDA, C. A. P de; NETO, E. L. M.; NETTO, A. de O. A. Caracterização morfométrica da sub-bacia do rio Poxim-Açu, Sergipe, Brasil. Revista Ambiente \& Água, v. 9, n. 2, 2014.

RODRIGUES, R. S. S.; FERNANDES, L. L.; CRISPIM, D. L.; VIEIRA, A. S. DE A.; PESSOA, F. C. L. Caracterização Morfométrica da Bacia Hidrográfica do Igarapé da Prata, Capitão Poço-Pará - Brasil. Revista Verde de Agroecologia e Desenvolvimento Sustentável., v. 11, n. 3, p. 143-150, 2016.

https://doi.org/10.18378/rvads.v11i3.4313

SAITO, N. S. Modelos digitais de elevação na sub - bacia hidrográfica do Córrego Horizonte, Alegre Espírito Santo. 2011. 120 f. Dissertação (Mestrado em Ciências Florestais) - Faculdade de Ciências Agrárias, Universidade Federal do Espirito Santo, Jerônimo Monteiro, 2011.

SANTOS, A. do C. Pedogênese e alterações geoquímicas em topolitossequências na Bacia do Ribeirão do Cachimbal na Região do Médio Vale do Paraíba, RJ. 2009. 241 f. Tese (Doutorado em Agronomia, Ciência do Solo). Instituto de Agronomia, Departamento de Solos. Universidade Federal Rural do Rio de Janeiro, RJ, 2009.

SANTOS, A. M.; TARGA, M. S.; BATISTA, G. T.; DIAS, N. W. Análise morfométrica das sub-bacias hidrográficas Perdizes e Fojo no município de Campos do Jordão, SP, Brasil. Revista Ambiente \& Água, v. 7 , n. 3, p. 195-211, 2012. https://doi.org/10.4136/ambi-agua.945

SANTOS, G. L. Efeito da Pedoforma no Processo de Sucessão Secundária em Fragmentos Florestais na Região do Médio Vale do Paraíba do Sul, Pinheiral, RJ. 2014. 130 p. Dissertação (Mestrado em Ciências Ambientais e Florestais). Instituto de Florestas, Universidade Federal Rural do Rio de Janeiro, Seropédica, 2014. 
SANTOS, R. D. dos.; SANTOS, H. G. dos.; KER, J. C.; ANJOS, L. H. C. dos; SHIMIZU, S. H. Manual de descrição e coletas de solos no campo. 7.ed. Viçosa, MG: Sociedade Brasileira de Ciência do Solo, 101 p., 2015.

SILVA, E. R. da ; DELGADO, R. C.; SOUZA, L. P. DE; SILVA, I. S. DA. Caracterização física em duas bacias hidrográficas do Alto Juruá, Acre. Revista Brasileira de Engenharia Agrícola e Ambiental, v. 18, n. 7, p. 714-719, 2014. https://doi.org/10.1590/S1415-43662014000700007

SOARES, D. DA S.; SILVA, E. P. DA; OLIVEIRA, A. S. DE; SILVA, A. C. S. DA; VEIGA, J. B. da. Análise Morfológica, Hidrológica e Ambiental dos Cursos D'água de Parte da Comunidade Central, Na Microbacia Mariana do Município de Alta Floresta - MT. Enciclopédia Biosfera, v. 10, n. 19; p. 2685, 2014.

SOUZA, A. C. M.; SILVA, M. R. F.; DIAS, N. da F. Gestão de Recursos Hídricos: O Caso da Bacia Hidrográfica Apodi/Mossoró (RN). Irrigação, Edição Especial, p. 280 - 296, 2012.

SOUZA, S. O. ;VALE, C. C. DO;NASCIMENTO, F. H. Bacia do rio peruípe (BA): ensaio de classificação morfométrica por meio de dados SRTM. Caminhos de Geografia Uberlândia v. 14, n. 47,2013.

STIPP, N. A. F.; CAMPOS, R. A.; CAVIGLIONE, J.H. Análise Morfométrica da Bacia Hidrográfica do Rio Taquara - uma Contribuição para o Estudo das Ciências Ambientais. Portal da Cartografia, Londrina v. 3 n. 1, 2010.

TEODORO, V. L. I. ; TEXEIRA, D.; COSTA, D. J. L.; FULLER, B. B. O conceito de bacia hidrográfica e a importância da caracterização morfométrica para o entendimento da dinâmica ambiental local. Revista Uniara, n. 20, 2007.

TONELLO, K. C.; DIAS, H. C. T.; SOUZA, A. L.; RIBEIRO, C. A. A. S.; LEITE, F. P. Morfometria da bacia hidrográfica da cachoeira das pombas, Guanhães - MG. Revista Árvore, v. 30, n. 5, p. 859-857, 2006. https://doi.org/10.1590/S0100-67622006000500019

TONELLO, K. C. Análise Hidroambiental da Bacia Hidrográfica da Cachoeira das Pombas, Guanhães, MG. Viçosa, 2005. 69p. Tese (Doutorado em Ciências Florestal) - Universidade Federal de Viçosa.

TORRES, J. L. R.; PEREIRA, M. G.; OLIVEIRA, F. A. DE; PAIVA, J. DE; CORNÉLIO, E. DE P.; FERNANDES, F. S. Análise das características quantitativas e qualitativas da microbacia do córrego barreiro, afluente do rio Uberaba. Revista Árvore, Viçosa-MG, v. 35, n. 4, p. 931- 939, 2011.

VALLE JUNIOR, R. F. DO; GALBIATTI; J. A.; PISSARRA, T. C. T.; FILHO, M. V. M. Caracterização morfométrica da bacia do rio Uberaba e determinação do uso potencial do solo, Uberaba-MG. Revista Caminhos de Geografia, v. 13, n. 44, p. 60-74 2012.

VIEIRA, D. M. da S.; TORRES, J. L. R.; OLIVEIRA, L. M. de; GONÇALVES, O. R.; OLIVEIRA, M. A. de. Morfometria e Qualidade da Água da Microbacia do Córrego do Sapecado, Afluente do Rio Uberaba-MG.

Global Science and Technology, v. 05, n. 03, p. $11-22,2012$.

VILLELA, S. M.; MATTOS, A. Hidrologia aplicada. São Paulo: McGraw-Hill do Brasil, 245p., 1997. 